\title{
Stolarsky type means related to an extension of Hölder-type inequality
}

\section{KSENIJA SMOLJAK}

\section{ABSTRACT.}

In this paper linear functionals related to an extension of Hölder-type inequality are defined and their $n$-exponential convexity is proved. Furthermore, new Stolarsky type means, using families of exponentially convex functions, are defined and their monotonicity property is proved.

Acknowledgements. This work has been fully supported by Croatian Science Foundation under the project 5435.

\section{REFERENCES}

[1] Bernstein, S. N., Sur les fonctions absolument monotones, Acta Math., 52 (1929), 1-66

[2] Mitrinović, D. S. and Pečarić, J. E., On some Inequalities for Monotone Functions, Boll. Unione. Mat. Ital., 7 (1991), 5-13, 407-416

[3] Mitrinović, D. S. and Pečarić, J. E., On the Bellman generalization of Steffensen's inequality III, J. Math. Anal. Appl., 135 (1988), $342-345$

[4] Pearce, C. E. M. and Pečarić, J. E., On an extension of Hölder's inequality, Bull. Austral. Math. Soc., 51 (1995), 453-458

[5] Pečarić, J. and Smoljak, K., Improvement of an extension of Hölder-type inequality, Anal. Math., 38 (2012), No. 2, 135-146

[6] Stolarsky, K. B., Generalization of the logarithmic mean, Math. Mag., 48 (1975), 87-92

UNIVERSITY OF ZAGREB

Faculty of TeXtile Technology

PRILAZ BARUNA FILIPOVIĆA 28A, 10000, ZAGREB, CROATIA

E-mail address: ksmoljak@ttf.hr 